\title{
Susceptibility of Three Legume Species to Callosobruchus maculatus (Coleoptera: Chrysomelidae) Attack and Impact of Rearing Medium on Female Oviposition Host Preference
}

\author{
D Kosini* and EN Nukenine \\ Department of Biological Sciences, University of Ngaoundere, Africa
}

Submission: May 24, 2017; Published: June 27, 2017

"Corresponding author: D Kosini, Department of Biological Sciences, University of Ngaoundere, Cameroon, Africa, Tel: +237674143908; Email: kosinid@yahoo.fr

\begin{abstract}
Experiments were conducted to determine the host preference of cowpea weevils Callosobruchus maculatus F. (Coleoptera: Chrysomelidae) using three pulses (Vigna unguiculata (L.) Walp., Vigna subterranea (L.) Verdc and Glycine max (L.) Merr.) and the susceptibility of these seeds to the beetle. Susceptibility was assessed using parameters like fecundity, developmental period and progeny production of bruchids. C. maculatus cultures were maintained separately on the three commodities for the host preference experiments and on cowpea for the susceptibility experiments. Seeds of each of the pulse species were introduced into partitioned petri dishes for the former and into glass jars for the latter experiments, and infested with C. maculatus. In the fecundity experiment, the maximum number of eggs was recorded on soybean and the minimum on cowpea. The developmental period of insects was two times longer in soybean than in cowpea and Bambara groundnut. Egg-toadult survivorship was highest for eggs laid on cowpea and lowest for those ones laid on soybean. Thus, Cowpea and Bambara groundnut are more susceptible to $C$. maculatus, whereas soybean is far less susceptible. In the choice experiment involving the three pulses, although there was an improvement in oviposition by $C$. maculates on their natal host. In stores containing cowpea and soybean, control measures for $C$. maculatus should target mainly cowpea. However, in storage facilities containing a mixture of pulses, control strategies should consider all the commodities since $C$. maculatus has the ability of better adapting to Bambara groundnut from cowpea and to soybean from Bambara groundnut.
\end{abstract}

Keywords: Pulses; Callosobruchus maculates; Susceptibility; Adaptability

\section{Introduction}

Dried seed legumes are of major importance to the livelihoods of millions in less developed countries. However, pulses are subject to attack by many groups of biodeteriorative agents, of which bruchids are the most important. The pulse beetle, Callosobruchus maculatus (F.), is a key pest to several grain legumes [1]. It starts infestation in the field, but heavy damage is done in storage [2]. It prefers to feed and develops on cowpea (Vigna unguiculata), but it is also known to feed on other legume seeds of which Bambara groundnut (Vigna subterranea) and soybean (Glycine max) [3].

The largest quantity of food in the tropics is stored in traditional farmer's granaries [4] and in most cases under one roof [5]. This type of storage may lead to cross infestation among the stored products, which are sharing a common pest.
Knowledge of suitable host, pest and the environment interaction is an important prerequisite when devising a costeffective pest management package. Moreover, it is important to know the host range of a polyphagous pest like C. maculatus, so that storage planning can be made to avoid cross-infestation among susceptible legume seeds species when stored under one roof or in a same store. This will prevent a heavy build-up of $C$. maculatus populations and their adaptability to less preferred host plant.

The present study was undertaken to determine the susceptibility of cowpea ( $V$. unguiculata), Bambara groundnut (V. subterranea) and soybean (G. $\max$ ) to pulse beetle attack and the adaptability of insect to the lower quality hosts (soybean) in store facilities containing the mixture of pulses. 


\section{Materials and Methods}

\section{Insect and commodities}

Insect and plant materials used were originally collected in Mokolo market, Mayo-Tsanaga division in far north Cameroon in May 2011, and subsequently insects were reared in the laboratory on cowpea, Bambara groundnut and soybean of the variety "Karantchi", "Kodek" and "TGx849-294D" respectively. Insects were reared for two generations before used for experiments.

Intact whole grains were chosen for the experiments, cleaned and disinfested by keeping them in a freezer at $4{ }^{\circ} \mathrm{C}$ for 21 days prior to the bioassays. The grains were then kept under the experimental conditions for at least 2 weeks before use. The moistures content of the seeds were $12.34 \pm 0.02 ; 11.86 \pm 0.27$ and $10.86 \pm 0.07$ respectively for cowpea, Bambara groundnut and soybean, determined using the method of AFNOR [6].

\section{Host preference}

choice experiment: The experiments were conducted under laboratory conditions $\left(\mathrm{t}=23.71-25.00{ }^{\circ} \mathrm{C}, \mathrm{hr}=73.41-75.72 \%\right)$. Five pairs of freshly emerged adults of $C$. maculatus were introduced in each replication comprising of 50 grams sample placed in a glass jar covered with muslin cloth and perforated covers. Weevils were allowed to mate and oviposit till the death of females. Thereafter, each grain was examined separately with a magnifying glass and the number of eggs laid was counted for each replication.

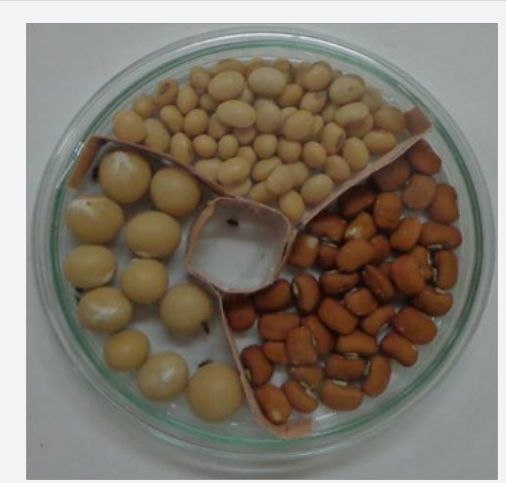

Figure 1: Experimental device for assessment of female oviposition host preference in free choice situation

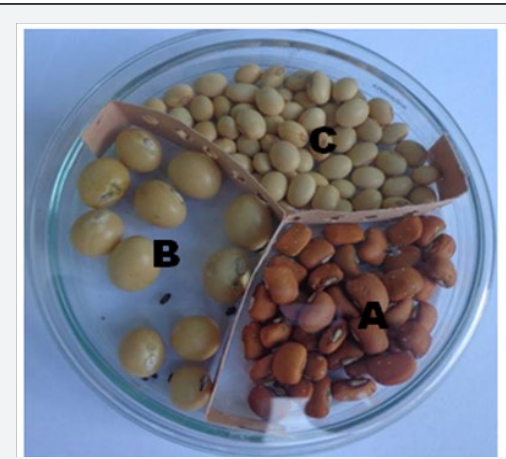

Figure 2: Experimental device for assessment of female oviposition host preference in directed choice situation.
Choice experiments (free and directed): The aim of this experiment was to assess the preference of host legume (cowpea, Bambara groundnut and soybean) by C. maculatus for oviposition under laboratory conditions at Ngaoundere, Cameroon $\left(\mathrm{t}=22.00-24.50{ }^{\circ} \mathrm{C}, \mathrm{hr}=72.50-84.00 \%\right)$ and then to carry out behavioral cross infestation of grains legumes by the insect when stored under the same roof or when alternated in the granary for storage. Indeed, in African stores insects may be in the infested products or out the products, and cross infestation may be changed according to these two insect's situations. So, two separately bioassays were conducted in petri dishes using central arena device (for free choice) and compartmental device without central arena (for directed choice) (Figure 1 \& 2) corresponding respectively to insect situation out and inside the stored products. Experiments were carried out in a completely randomized design (CRD) using 3 pulse species $x 3$ rearing mediums replicated eight times.

Glass petri dishes of $9 \mathrm{~cm}$ in diameter and $1.2 \mathrm{~cm}$ in height were equipped with cardboard paper into three sections and perforated circular central arena of $2 \mathrm{~cm}$ diameter in which six couples of newly emerged cowpea weevils less than 2 hours old from each rearing medium (cowpea, Bambara groundnut or soybean) were separately introduced. Cowpea, Bambara groundnut and soybean, $7.5 \mathrm{~g}$ each were separately introduced into the different sections of the device, prior to introduce the insects in the central arena (Figure 1). Fecundity was determined by counting the number of eggs in each section after the death of females.

The second bioassay was carried out as described in previous paragraph, but insects were introduced in the section which contained sample of their natal host (Figure 2).

Assessment of the susceptibility of seeds to infestation by Callosobruchus maculates: Seeds (50g) of each legume species were introduced into a glass jar. Ten pairs of bruchids freshly emerging from cowpea were taken and introduced into a glass jar. The jar was then covered with perforated covers. The experiment was replicated four times.

Six days after infestation the adults were removed while observations for emergence started three weeks after infestation. Emergence was recorded every day at the same hour still the end. The susceptibility index (SI) was calculated following the formula used by Dobie [7]:

$$
\mathrm{SI}=(\text { Loge F1/D) } \times 100
$$

where:

\section{F1- total number of emerged adults}

D-median developmental period (estimated as the time from the middle of oviposition to the emergence of $50 \%$ of the F1 generation.

The Dobie Index [8] was used to classify the varieties into groups following the scales as follows: scale index of $\leq 4$ was 
classified as resistant; scale index of 4.1-6.0 as moderately resistant; scale index of $6.1-8.0$ as moderately susceptible; scale index of 8.1-10 as susceptible; and scale index of $>10$ was classified as highly susceptible.

\section{Statistical analysis}

Data with abnormal distribution were transformed by using $\sigma x+0.5$ formula before statistical analysis. Analyses of variance (ANOVA) using the Statistical Analysis System [8] were done on the data. Tukey's test $(\mathrm{P}=0.05)$ was applied for means separation.

\section{Results}

\section{Female oviposition host preference}

In no choice experiment, results (Table 1 ) indicated that the maximum number of eggs was recorded on soybean and the minimum on cowpea. However, means were not significantly different between Bambara groundnut and soybean. Accordingly, the fecundity of bruchids infesting soybean and Bambara groundnut was higher than that for those infesting cowpea. Egg-to-adult survivorship was highest for eggs laid on cowpea (92\%) followed by Bambara groundnut (62\%). On soybean high mortality occurred and only 39\% of eggs laid developed and reached the adult stage.

Table 1: Fecundity and egg survivorship of Callosobruchus maculatus on stored cowpea, Bambara groundnut and soybean

\begin{tabular}{|c|c|c|c|}
\hline Commodity & $\begin{array}{c}\text { Total Number } \\
\text { of Eggs Laid } \\
\text { (Mean } \pm \text { SE) }\end{array}$ & $\begin{array}{c}\text { Female } \\
\text { Fecundity } \\
\text { (Mean } \pm \text { SE) }\end{array}$ & $\begin{array}{c}\text { Survival } \\
\text { (\%) }\end{array}$ \\
\hline Cowpea & $202.00 \pm 6.24 \mathrm{~b}$ & $40.40 \pm 1.25 \mathrm{~b}$ & $92 \mathrm{a}$ \\
\hline B. groundnut & $239.00 \pm 12.00 \mathrm{ab}$ & $47.80 \pm 2.40 \mathrm{ab}$ & $62 \mathrm{~b}$ \\
\hline Soybean & $272.33 \pm 20.50 \mathrm{a}$ & $54.47 \pm 4.10 \mathrm{a}$ & $39 \mathrm{c}$ \\
\hline F2,9 & $6.157^{*}$ & $6.157^{*}$ & $27.07^{* *}$ \\
\hline
\end{tabular}

*: $\mathrm{P}<0.05 ;{ }^{* *}: \mathrm{P}<0.01$

B. groundnut: Bambara groundnut

Means followed by the same letter within a column did not differ significantly at the $5 \%$ level by Tukey's test

Table 2: Callosobruchus maculatus female oviposition preference on three legumes species (Vigna unguiculata, Vigna subterranea and Glycine max) in a free choice experiment

\begin{tabular}{|c|c|c|c|c|}
\hline \multirow{2}{*}{$\begin{array}{l}\text { Insect } \\
\text { Rearing } \\
\text { Medium }\end{array}$} & \multicolumn{3}{|c|}{ Commodities } & \multirow[b]{2}{*}{$\mathbf{F}$} \\
\hline & Cowpea & $\begin{array}{c}\text { B. } \\
\text { Groundnut }\end{array}$ & Soybean & \\
\hline \multirow{2}{*}{ cowpea } & $99.00 \pm$ & $36.00 \pm$ & \multirow{2}{*}{$1.00 \pm 0.00 \mathrm{Cc}$} & \multirow{2}{*}{$573.02^{* * *}$} \\
\hline & $3.00 \mathrm{Aa}$ & $3.00 \mathrm{Bb}$ & & \\
\hline \multirow{2}{*}{$\begin{array}{c}\text { B. } \\
\text { groundnut }\end{array}$} & $69.00 \pm$ & $55.00 \pm$ & \multirow{2}{*}{$33.00 \pm 1.00 \mathrm{Cb}$} & \multirow{2}{*}{$41.07^{* * *}$} \\
\hline & $4.00 \mathrm{Ab}$ & $4.00 \mathrm{Ba}$ & & \\
\hline \multirow{2}{*}{ soybean } & $51.00 \pm$ & $59.00 \pm$ & \multirow{2}{*}{$55.00 \pm 3.00 \mathrm{Aa}$} & \multirow{2}{*}{$1.67 \mathrm{~ns}$} \\
\hline & $2.00 \mathrm{Ac}$ & $3.00 \mathrm{Aa}$ & & \\
\hline $\mathrm{F}$ & $70.82^{* * *}$ & $15.31^{* * *}$ & $396.08^{* * *}$ & \\
\hline
\end{tabular}

NS: not significant, ${ }^{* *}: \mathrm{P}<0.001$

B. groundnut: Bambara groundnut
Means within the column and line followed respectively by the same small and capital letter did not differ significantly at the $5 \%$ level by Tukey's test.

Table 3: Callosobruchus maculatus female oviposition preference on three legumes species (Vigna unguiculata, Vigna subterranea, Glycine max) in a directed choice experiment.

\begin{tabular}{|c|c|c|c|c|}
\hline \multirow{2}{*}{$\begin{array}{c}\text { nsect } \\
\text { rearing } \\
\text { medium }\end{array}$} & Cowpea & B. Groundnut & Soybean & \multirow{2}{*}{ F } \\
\cline { 2 - 4 } & $72.00 \pm$ & $31.00 \pm$ & $4.00 \pm$ & \multirow{2}{*}{$215.24^{* * *}$} \\
\hline cowpea & $3.00 \mathrm{Aa}$ & $3.00 \mathrm{Bb}$ & $1.00 \mathrm{Cc}$ & \\
\hline $\begin{array}{c}\mathrm{B} . \\
\text { groundnut }\end{array}$ & $58.00 \pm$ & $64.00 \pm$ & $40.00 \pm$ & \multirow{2}{*}{$17.05^{* * *}$} \\
\hline \begin{tabular}{c} 
soybean \\
\hline $\mathrm{F}$
\end{tabular} & $5.00 \mathrm{Ab}$ & $4.00 \mathrm{Aa}$ & $2.00 \mathrm{Ba}$ & \\
\hline & $2.00 \mathrm{Ab}$ & $3.00 \mathrm{Aa}$ & $3.00 \mathrm{Bb}$ & \multirow{2}{*}{$49.18^{* * *}$} \\
\hline
\end{tabular}

***:P<0.001

B. groundnut: Bambara groundnut

Means within the column and line followed respectively by the same small and capital letter did not differ significantly at the $5 \%$ level by Tukey's test.

The oviposition preferences of $C$. maculatus for its host plants was strongly influenced by the type of substrate from which females emerged $(\mathrm{F}=17.05-573.02, \mathrm{P}<0.001)$. Overall, there was an improvement of female oviposition preference for the host plant on which it was reared. Females emerged from cowpea preferred twice as much cowpea than Bambara groundnut as oviposition sites and soybean was almost completely rejected, either in the free or directed choice (Table $2 \& 3$ ). Adults emerged from Bambara groundnut had the same preference for cowpea and Bambara groundnut and greatly improved their preference for soybean. There was no ovipositional preference $(F=1.67, N S)$ for bruchids reared on soybean in situation of free choice (Table $2)$, while in directed choice soybean was less preferred than cowpea and Bambara groundnut (Table 3).

From the previous, we can conclude that female emerged from cowpea had high preference for cowpea than those one emerged from Bambara groundnut and soybean; these one emerged from Bambara groundnut and soybean had the same preference for Bambara groundnut and this was higher than that for those one emerged from cowpea. Soybean was more preferred by females emerged from soybean followed by those one emerged from Bambara groundnut, in the situation of free choice.

\section{Pulse susceptibility to insect attack}

The developmental period (days) of $C$. maculatus on seeds of cowpea, Bambara groundnut and soybean showed a significant difference among them $(\mathrm{F} 2,9=1860.00, \mathrm{P}<0.001)$. Data given in Table 4 indicate that the longest developmental period of $C$. maculatus was recorded on soybean (60.5 days) while shortest (30.5 days) on cowpea. Table 4 further shows that significantly 
$(\mathrm{F}=23.88, \mathrm{P}<0.001)$ more adults emerged from cowpea (282.5) and Bambara groundnut (221) and lowest (106) from soybean.

Table 4: Susceptibility parameters of cowpea, Bambara groundnut and soybean to Callosobruchus maculatus attack.

\begin{tabular}{|c|c|c|c|c|}
\hline Commodities & $\begin{array}{c}\text { Adults } \\
\text { Emerged } \\
\text { (Mean } \pm \\
\text { SE) }\end{array}$ & $\begin{array}{c}\text { MDP ( } \pm \\
\text { SE) }\end{array}$ & $\begin{array}{l}\text { SI (Mean } \pm \\
\text { SE) }\end{array}$ & $\begin{array}{c}\text { Reaction } \\
\text { To Insect } \\
\text { Attack }\end{array}$ \\
\hline cowpea & $\begin{array}{c}282.50 \pm \\
12.14 \mathrm{a}\end{array}$ & $\begin{array}{c}30.50 \pm \\
0.29 c\end{array}$ & $\begin{array}{c}18.58 \pm \\
0.30 \mathrm{a}\end{array}$ & $\begin{array}{c}\text { very } \\
\text { susceptible }\end{array}$ \\
\hline B. groundnut & $\begin{array}{c}221.00 \pm \\
29.29 a\end{array}$ & $\begin{array}{c}35.50 \pm \\
0.50 \mathrm{~b}\end{array}$ & $\begin{array}{c}15.13 \pm \\
0.99 \mathrm{a}\end{array}$ & $\begin{array}{c}\text { very } \\
\text { susceptible }\end{array}$ \\
\hline Soybean & $\begin{array}{c}106.00 \pm \\
8.66 \mathrm{c}\end{array}$ & $\begin{array}{c}60.50 \pm \\
0.29 a\end{array}$ & $\begin{array}{l}7.69 \pm \\
0.14 b\end{array}$ & $\begin{array}{l}\text { Moderately } \\
\text { susceptible }\end{array}$ \\
\hline$F 2,9$ & $23.88^{* * *}$ & $1860.00^{* * *}$ & $411.54^{* * *}$ & \\
\hline
\end{tabular}

***: $\mathrm{P}<0.001$

Means followed by the same letter do not differ significantly at the $5 \%$ level by Tukey's test

MDP: Mean Developmental Period, B. groundnut: Bambara groundnut.

It was also observed that the pulse with short developmental period and high number of emerged adults had the highest susceptibility index and consequently suffered from heavy damage caused by bruchids. Cowpea and Bambara groundnut seeds with the highest susceptibility index were termed as very susceptible to insect attack and soybean which had the lowest susceptibility index was termed as moderately susceptible.

\section{Discussion}

The physical characteristics of seeds can determine the acceptability for oviposition and may be also related to the chemical nature of the seed [9]. From this study smooth seeds (soybean and Bambara groundnut) were more accepted than the rough ones (cowpea) by $C$. maculatus females for oviposition in the no choice experiment. This is an accordance with the result reported [10] who showed that rough seeds were less acceptable to $C$. maculatus than smooth ones. Because the roughness makes seeds unsuitable for oviposition, females might perhaps laid additional eggs on the surface of glass jars containing cowpea seeds.

In the choice experiment, there was a significant association between the seeds preferred for oviposition and culture on which the bruchid was reared. There may be an interaction between plant secondary chemical substances and physiological adaptations in insects to such compounds. Our results are in accordance with similar study which found that with Caryedon cerratus there was an association between host preference and previous conditioning of the bruchids on their hosts [11]. Also, Messina [12] asserted that females prefer to lay eggs on their natal host. However, Bambara groundnut and soybean were not respectively rejected by the bruchids reared on cowpea and Bambara groundnut in our investigations. Moreover, for both sets of choice experiments, results suggested that a low quality host pre-adapts beetles for a switch to a higher quality host and beetles adapted to a lower quality host (soybean) may be more successful on the other poor or better quality host (Bambara groundnut) than beetles adapted to a higher quality host (cowpea), with respect to oviposition. This pre-adaptation of cowpea beetles to a poor quality hosts with respect to oviposition may be often less important than the suitability of host plant for insect development and larvae survivorship, on the rate of infestation.

The bad quality of food can delay insect development when feeding inside the grain. So, developmental period is appreciably prolonged in soybean, because it is not a suitable host plant. [13] reported that soybean contains saponins and that some saponins display a significant anti-mitotic activity; they inhibit the growth of cells without destroying them. This might explain the inability of $C$. maculatus to utilize the higher protein content of soybean and the resultant prolonged developmental period. The rate of multiplication of $C$. maculatus on cowpea and Bambara groundnut was two times faster than that on soybean.

According to this study the number of insect adult that emerged from the three commodities was negatively correlated with developmental period and there was no association with the eggs number deposited on each commodity. This is in agreement to the previous finding [3] where lower adults emerged from soybean $(18.8 \%)$ than from Bambara groundnut $(58.3 \%)$ and cowpea (88.1\%). The difference may be due to ability or inability of larvae to utilize the food material that may be responsible to higher larvae mortality, up to $61 \%$ on soybean. Another reason may be the level of moisture content of each commodity, since the number of adult that emerged increased with ascending grain moisture content; this because, the hardness of the seed-coat seems to be a limiting factor of larvae, when penetrating through the seed-coat. Hence, grain legumes belong to Vigna genus should be regarded as most suitable host and soybean that belong to Glycine as poor host. As regards their susceptibility index and Dobie [7] classification cowpea and Bambara groundnut are subjected to higher quantitative losses than soybean, by insect attack when not protected. However, soybean might also suffer from heavy damage by insect attack during long storage period, especially in store containing cowpea and Bambara groundnut. As previously described insects emerged from cowpea had some ovipositional preference for Bambara groundnut and these one emerged from Bambara groundnut for stored soybean. Under the circumstances, cross infestation might occur and the rapid adaptation of female beetles to the poor quality host (soybean) might lead to an acceleration of the rate of larval development as reported previously [14].

\section{Conclusion}

Cowpea and Bambara groundnut are very susceptible to pulse beetles attack. Bambara groundnut constitute an 
intermediate host for infestation of soybean in store facilities containing the mixture of pulses. In stores containing cowpea and soybean, control measures for $C$. maculatus should then target mainly cowpea. However, in storage facilities containing a mixture of pulses, control strategies should consider all the commodities since $C$. maculatus has the ability of better adapting to other pulses.

\section{Acknowledgement}

The authors are grateful to the Department of Annual Crops, IRAD (Institute of Agricultural Research for Development) of Maroua where pulses were identified.

\section{Conflict of Interest}

The authors declare that they have no conflict of interest.

\section{References}

1. Lale NES (2002) Stored Products Entomology and Acarology. In: Tropical Africa, $\left(1^{\text {st }}\right.$ edn), Mole Publications (NiSi) Ltd., Maiduguri, Nigeria.

2. Douma A, Liman AI, Toudou ATA, Alzouma I (2006) Comportement de vingt variétés de niébé (Vigna unguiculata (L.) Walp) vis-à-vis de Bruchidius atrolineatus (Pic) et Callosobruchus maculatus (F.) (Coleoptera: Bruchidae). Cahiers Agriculture 15(2): 187-193.

3. Swella BG, Mushobozy DMK (2009) Comparative susceptibility of different legume seeds to infestation by cowpea Bruchid Callosobruchus maculatus (F.) (Coleoptera: Chrysomelidae). Plant Protection Science 45(1): 19-24.

4. Ngamo TSL, Ngassoum MB, Mapongmetsem PM, Malaisse F, Haubruge E, et al. (2007) Current post harvest practices to avoid insect attacks on stored grains in Northern-Cameroon. Agricultural Journal 2(2): 242247.
5. Stathers TE, Chigariro J, Mudiwa M, Mvumi BM, Golob P (2002) Smallscale farmer perceptions of diatomaceous earth products as potential stored grain protectants in Zimbabwe. Crop Protection 21: 1049-1060.

6. AFNOR (Association Française de Normalisation) (1982) Recueil de normes françaises des produits dérivés des fruits et légumes. ( $1^{\text {st }}$ edn), Association française de normalisation, AFNOR, Paris, France.

7. Dobie P (1974) The laboratory assessment of the inherent susceptibility of maize varieties to post-harvest infestation by Sitophilus zeamais Motsch. (Coleoptera: Curculionidae). Journal of Stored Products Research 10: 183-197.

8. SAS Institute (2003) The SAS system version 9.1 for windows. SAS Institute, Cary, USA.

9. Messina FJ, Renwick JAA (1985) Resistance to Callosobruchus maculatus (Coleoptera: Bruchidae) in selected cowpea lines. Environmental Entomology 14(6): 868-872.

10. Sarwar M (2012) Assessment of resistance to the attack of bean beetle Callosobruchus maculatus (Fabricius) in chickpea genotypes on the basis of various parameters during storage. Songklanakarin J Sci Technol 34(3): 287-291.

11. Ouedraogo I, Traore NS, Guenda W, Dabire LCB (2010) Influence des plantes hôtes sur la bruche de l'arachide Caryedon serratus Olivier (Coleoptera: Bruchidae) au Burkina Faso. J of Appl Biosci 31: 19061915.

12. Messina FJ (2004) How labile are the egg-laying preferences of seed beetles? Ecological Entomology 29(3): 318-326.

13. Sodipo OA, Ayalogu EO (1999) Environnement management. Journal of Applied Science 2: 5-8.

14. Fricke C, Arnqvist G (2007) Rapid adaptation to a novel host in a seed beetle (Callosobruchus maculatus): the role of sexual selection. Evolution 61(2): 440-454.

\begin{tabular}{|l|}
\hline \multicolumn{1}{|c|}{ Your next submission with Juniper Publishers } \\
will reach you the below assets \\
- Quality Editorial service \\
- Swift Peer Review \\
- Reprints availability \\
- E-prints Service \\
- Manuscript Podcast for convenient understanding \\
- Global attainment for your research \\
- Manuscript accessibility in different formats \\
( Pdf, E-pub, Full Text, Audio) \\
- Unceasing customer service \\
Track the below URL for one-step submission \\
https://juniperpublishers.com/online-submission.php \\
\hline
\end{tabular}

